\title{
Consumption patterns in Sri Lanka: a decomposition analysis
}

\author{
Shashika D. Rathnayaka ${ }^{\mathrm{a}, \mathrm{b}}$, E. A. Selva Selvanathan ${ }^{\mathrm{a}}$ and Saroja Selvanathan (1) ${ }^{\mathrm{a}}$ \\ ${ }^{a}$ Griffith Business School, Griffith University, Brisbane, Australia; ${ }^{b}$ Department of Export Agriculture, Uva Wellassa University, Badulla, Sri \\ Lanka
}

\begin{abstract}
Knowing consumer reaction to changes in prices and income is important in formulating microeconomic policies, such as public utility prices and commodity taxation. This paper analyses the consumption patterns of consumer goods grouped into eight broad commodities in Sri Lanka during the period 1975-2016, using a system-wide framework. The analysis indicates that Sri Lankan consumers allocate more than half of their income to food and nearly four fifths of their income to food, housing, and transport combined. The estimated income and own-price elasticities reveal that food, housing, medical care, and transport are necessities; clothing, durables and recreation are luxuries; and demand for all commodities is price inelastic except for recreation. To investigate the consumption growth pattern, we decomposed the growth in consumption and change in budget shares of the eight commodities into income, relative price, and change in taste. We also simulated per capita consumption expenditure of the eight commodities under various policy scenarios and found that income growth has played a significant role in Sri Lankan consumption patterns.
\end{abstract}

\section{KEYWORDS}

Consumer demand; demand elasticities; demand theory hypotheses; decomposition analysis; simulations

\section{JEL CLASSIFICATION}

D12; C10

\section{Introduction}

In most countries, consumption plays a dominant role in national income, which is the largest component of GDP. Therefore, analysing the consumption patterns of consumers of a country is of crucial importance for that country's policy makers in government departments in designing their country's own economic plan and for other policy makers in the government and various industries of other countries in determining the market for their exports. More importantly, knowing consumer reaction to changes in prices and income is important in formulating microeconomic policies such as public utility prices and commodity taxation. Demand elasticities are useful concepts to describe how consumers react to change in prices and income. Economists and policy makers require numerical estimates of the demand and price elasticities in many instances. For example, they are essential inputs in computations of optimal taxation, tax reforms, and in applied computable general equilibrium (CGE) models.

While elasticity estimates can be used to measure the change in consumer demand for changes in income and prices, it is also desirable to know the level of contribution of income and prices on consumer expenditure whenever changes in income or commodity prices occur. This is an important matter when the distributional effects of various policies are to be considered along with the corresponding changes in demand (Karagiannis and Velentzas 2004). Therefore, along with the estimation of demand elasticities, it is imperative to develop an alternative framework to analyse the changes in consumer demand and simulate the consumption under various policy scenarios.

Few studies in the literature have decomposed the changes in consumer demand or expenditure shares above and beyond the estimation of demand elasticities. Karagiannis and Velentzas (1997) decomposed changes in Greek food budget shares into three components: the total substitution effect, the budget (total expenditure) effect, and the habit effect. Their analysis is based on a dynamic specification of the Almost Ideal Demand System (AIDS) model. In another study, Heien and Wessells (1988) decomposed the changes in consumption of dairy products in the United States into economic and demographic 
effects using the estimated demand elasticities of AIDS. Karagiannis and Velentzas (2004) decomposed the changes in Marshallian demand or expenditure shares functions over time into a total substitution effect, an income effect, and a habit effect. They applied this framework to post-war Greek consumption patterns through a habit persistence version of the Quadratic Almost Ideal Demand System (QUAIDS). Dong (2006) decomposed the dairy product consumption growth in Asia into contributions generated by income growth, population growth, price change, and urbanisation using the technique used by Heien and Wessells (1988). Recently, Wong, Selvanathan, and Selvanathan (2015) decomposed the changes in the consumption of meat in Australia into effect of consumer preferences, income effect, own price effect, and cross price effect and the effect of residual component, using the Rotterdam model. The same study also simulated per capita consumption of meat under various policy scenarios. Selvanathan et al. (2016) decomposed the changes in meat and fish consumption changes in Saudi Arabia.

Unlike the above studies, the current study attempts to decompose the changes in consumer demand, in Sri Lanka. Located in the Asia Pacific region, Sri Lanka is a developing country with a population of 22 million people. It has implemented liberalised trade policies in the 1970s. Private consumption plays a significant role in the national income of the country and accounts for about $70 \%$ of GDP. According to our knowledge, there are no other recently published comprehensive econometric studies available that analyse the demand for the eight commodities in Sri Lanka in a system-wide manner using more recent data. However, there are very few empirical research studies that included Sri Lanka in their cross-country consumption comparison studies and they have looked at the consumption of commodity groups in Sri Lanka (for example see Deaton and Case 1987; Selvanathan and Selvanathan 2003; Clements, $\mathrm{Wu}$, and Zhang 2006). Only a few studies are available that focus on Sri Lanka as a single country demand study (Sahn 1988; Nigel and Bogahawatte 1990; Pradhan and Thudawe 1997; Kottage 1988; Rathnayake, Priyadarshanie, and
Weerahewa 2004; Weerahewa, Rajapakse, and Pushpakumara 2013; Edirisinghe 2014; Lokuge and Edirisinghe 2015; Nirmali and Edirisinghe 2015; Rathnayaka et al. 2018). However, most of these studies estimated a single commodity nutrition-specific demand equations specially aimed at food demand.

Our study differs from above studies in a number of ways. We use the system-wide approach together with the most recent available data and the most recent developments in econometrics and time series analysis, and we decompose the changes in consumer demand and simulate the per capita consumption expenditure of eight commodities under various policy scenarios.

The rest of the paper is organised as follows. A preliminary analysis of Sri Lankan consumption data are presented in Section 2. We present the demand system for estimation and test various demand theory hypotheses, in Section 3. Estimated results and the implied income and price elasticities are presented in Section 4. The results of decomposition analysis are reported in Section 5. The per capita consumption expenditure under various policy scenarios is simulated in Section 6. Finally, in Section 7, we present our concluding comments.

\section{Preliminary analysis of consumption data for Sri Lanka}

The basic data used in this study are the annual consumption expenditure (in current and constant prices) of goods and services, and the population of Sri Lanka for the period 1975-2016 $(\mathrm{T}=42)$. Data for the period 1975-1995 were drawn from various issues of the United Nations - Yearbooks of National Accounts Statistics while 1996-2016 data were taken from the United Nations database and various issues of Central Bank of Sri Lanka publications. Sri Lankan population data for the years 1975-2016 were also obtained from the United Nations database. Goods and services are classified into $(\mathrm{n}=8)$ commodities and are presented in Table 1 with a detailed description.

The proportion of the total expenditure allocated to commodity $i$ is known as the budget share of commodity $i$ and it is given by $w_{i t}=p_{i t} q_{i t} / M_{t}$, where $p_{\text {it }}$ and $q_{\text {it }}$ are the price and consumption of 
Table 1. Classification of eight commodities.

\begin{tabular}{|c|c|}
\hline $\begin{array}{l}\text { Commodity } \\
\text { Group }\end{array}$ & Description \\
\hline 1. Food & Food, Non-alcoholic and Alcoholic beverages \\
\hline 2. Clothing & Clothing and Footwear \\
\hline 3. Housing & Rent, Fuel and Power \\
\hline 4. Durables & $\begin{array}{l}\text { Furniture, Furnishings, Household equipment and } \\
\text { operation }\end{array}$ \\
\hline 5. Medical care & Medical care and Health expenses \\
\hline 6. Transport & Personal transport equipment and Communications \\
\hline 7. Recreation & $\begin{array}{l}\text { Educational, Recreational, Entertainment and } \\
\text { Cultural services }\end{array}$ \\
\hline 8. Miscellaneous & $\begin{array}{l}\text { Personal care, Expenditure in restaurants, Cafes and } \\
\text { Hotels and Other }\end{array}$ \\
\hline
\end{tabular}

good $\mathrm{i}$ in period $\mathrm{t}$. Table 2 gives the budget shares of each commodity group between 1975 and 2016 for the selected years. The last row of the table presents the mean budget shares averaged over the sample period. As can be seen, major change has taken place in the budget shares for food, housing, and transport. The budget share for food has fallen from $70.8 \%$ in 1975 to $41 \%$ in 2016 , whereas for housing, it has increased from $4.8 \%$ to $15.4 \%$, and the share for transport has considerably increased by nearly five times from $5.6 \%$ in 1975 to $25.5 \%$ in 2016 . Even though food share has declined over the years, it still dominates the expenditure share with an average of $53.6 \%$, followed by transport with $17.2 \%$. Medical care has the lowest average share of $1.7 \%$ over the sample period. On average, Sri Lankan consumers spend nearly $80 \%$ of their income on food, housing, and transport combined. This observation in the Sri Lankan consumption patterns is in line with that observed in most of other developing countries by a number of previous recent studies (for example, see Chen 2001; Selvanathan and Selvanathan 2006).

The first two rows of Table 3 present the mean (averaged over the sample period) of the price and quantity log-changes defined as as $D p_{i t}=\ln p_{i t}-$ $\ln p_{i t-1} \quad$ and $D q_{i t}=\ln q_{i t}-\ln q_{i t-1}$, respectively.
When multiplied by 100 , these log changes can be interpreted as percentage changes or percentage growth rates of price and consumption from year $\mathrm{t}-1$ to year t. Here and elsewhere $\ln$ refers to the natural logarithm. On average, individual prices grew annually at a rate of $9.65 \%$ for food, $7.66 \%$ for clothing, $8.24 \%$ for housing, $10.96 \%$ for durables, $11.63 \%$ for medical care, $8.51 \%$ for transport, and $7.41 \%$ for recreation. Clothing and recreation have the lowest average price growth rate, while medical care records the highest average price growth rate. The consumption of all eight commodities have a positive average growth rate with transport (8.1\%) the highest and food (2\%) the lowest growth rates. A comparison of mean relative prices and mean relative quantities, presented in the last two rows of Table 3, reveals that all pairs of relative price and relative consumption changes have the opposite sign supporting the demand law.

To measure the overall growth in prices and consumption, we use the first order Divisia moments, Divisia price index, and Divisia quantity index. The Divisia price and quantity indices are the weighted sum of individual price and quantity log changes which are defined as

$$
D P_{t}=\sum_{i=1}^{n} \bar{w}_{i t} D p_{i t} \quad \text { and } \quad D Q_{t}=\sum_{i=1}^{n} \bar{w}_{i t} D q_{i t}
$$

where $\bar{w}_{i t}=(1 / 2)\left(w_{i t}+w_{i, t-1}\right)$ is the arithmetic average of the budget shares in period $t$ and $t-1$. While Divisia price index measures the overall growth in prices, the Divisia quantity index measures the growth in per capita consumption (or real income). On average, overall prices $(D \bar{P})$ have increased at a rate of $9.13 \%$ per annum while consumption $(D \bar{Q})$ has increased at a rate of only $3.82 \%$ per annum in Sri Lanka.

Table 2. Budget shares of eight commodities (in percentages), Sri Lanka, selected years, 1975-2016.

\begin{tabular}{|c|c|c|c|c|c|c|c|c|}
\hline Year & $\begin{array}{l}\text { Food } \\
\text { (1) }\end{array}$ & $\begin{array}{l}\text { Clothing } \\
\text { (2) }\end{array}$ & $\begin{array}{l}\text { Housing } \\
\text { (3) }\end{array}$ & $\begin{array}{c}\text { Durables } \\
\text { (4) }\end{array}$ & $\begin{array}{c}\text { Medical } \\
\text { (5) }\end{array}$ & $\begin{array}{c}\text { Transport } \\
\text { (6) }\end{array}$ & $\begin{array}{c}\text { Recreation } \\
\text { (7) }\end{array}$ & $\begin{array}{c}\text { Miscellaneous } \\
\text { (8) }\end{array}$ \\
\hline 1975 & 70.8 & 7.4 & 4.8 & 3.2 & 1.4 & 5.6 & 3.2 & 3.7 \\
\hline 1980 & 61.7 & 6.0 & 5.8 & 4.9 & 1.7 & 12.1 & 3.9 & 4.2 \\
\hline 1985 & 56.4 & 7.1 & 5.9 & 4.7 & 1.6 & 16.5 & 4.8 & 3.1 \\
\hline 1990 & 59.1 & 6.4 & 4.6 & 5.1 & 1.7 & 15.4 & 3.6 & 4.2 \\
\hline 1995 & 57.6 & 8.2 & 4.0 & 5.7 & 1.9 & 15.9 & 3.1 & 3.7 \\
\hline 2000 & 51.4 & 9.4 & 7.3 & 4.5 & 1.6 & 17.1 & 3.1 & 5.5 \\
\hline 2005 & 41.7 & 9.2 & 10.6 & 6.4 & 1.6 & 22.3 & 2.8 & 5.5 \\
\hline 2010 & 42.2 & 6.4 & 12.0 & 5.3 & 2.1 & 24.0 & 3.0 & 5.1 \\
\hline 2016 & 41.0 & 4.7 & 15.4 & 4.3 & 2.0 & 25.5 & 2.8 & 4.3 \\
\hline Mean & 53.6 & 7.2 & 8.0 & 4.8 & 1.7 & 17.2 & 3.6 & 4.1 \\
\hline
\end{tabular}


Table 3. Mean price and quantity log-changes of eight commodities, Sri Lanka, 1975-2016.

\begin{tabular}{|c|c|c|c|c|c|c|c|}
\hline $\begin{array}{l}\text { Food } \\
(1)\end{array}$ & $\begin{array}{c}\text { Clothing } \\
\text { (2) }\end{array}$ & $\begin{array}{c}\text { Housing } \\
\text { (3) }\end{array}$ & $\begin{array}{c}\text { Durables } \\
\text { (4) }\end{array}$ & $\begin{array}{c}\text { Medical care } \\
\text { (5) }\end{array}$ & $\begin{array}{c}\text { Transport } \\
\text { (6) }\end{array}$ & $\begin{array}{l}\text { Recreation } \\
(7)\end{array}$ & $\begin{array}{l}\text { Miscellaneous } \\
\text { (8) }\end{array}$ \\
\hline \multicolumn{8}{|c|}{$\overline{\text { Mean price log-change }\left(D \bar{q}_{i}\right)}$} \\
\hline 9.65 & 7.66 & 8.24 & 10.96 & 11.63 & 8.51 & 7.41 & 9.82 \\
\hline \multicolumn{8}{|c|}{ Mean quantity log-change $\left(D \bar{q}_{i}\right)$} \\
\hline 1.97 & 4.17 & 7.55 & 2.74 & 2.18 & 8.13 & 5.23 & 3.48 \\
\hline \multicolumn{8}{|c|}{ Mean relative price log-change $\left(D \bar{q}_{i}-D \bar{P}\right)$} \\
\hline 0.51 & -1.47 & -0.89 & 1.83 & 2.49 & -0.62 & -1.72 & 0.69 \\
\hline \multicolumn{8}{|c|}{ Mean relative quantity log-change $\left(D \bar{q}_{i}-D \bar{Q}\right)$} \\
\hline-1.85 & 0.35 & 3.73 & -1.08 & -1.64 & 4.31 & 1.41 & -0.34 \\
\hline
\end{tabular}

Overall variation in prices and consumption can be measured by the Divisia price variance and the Divisia quantity variance defined as

$$
\Pi_{t}=\sum_{i=1}^{n} \bar{w}_{i t}\left[D p_{i t}-D P_{t}\right]^{2} \quad \text { and } \quad K_{t}=\sum_{i=1}^{n} \bar{w}_{i t}\left[D q_{i t}-D Q_{t}\right]^{2} .
$$

Figure 1 plots $\sqrt{K_{t}}$ against $\sqrt{\Pi_{t}}$ for the sample period $\mathrm{t}=1, \ldots, 41$ together with the $45^{\circ}$ line. As can be seen, a majority of the points lie above the $45^{\circ}$ line indicating that the quantity variance mostly systematically exceeds the price variance. This pattern agrees well with the observation made by Theil and Suhm (1981), Clements (1982, 1983), Selvanathan and Selvanathan (1993, 1994), Selvanathan and Clements (1995), Selvanathan and Selvanathan (2003), and Wong, Selvanathan, and Selvanathan (2017).

The relative consumption $\left(D q_{i t}-D Q_{t}\right)$ against the relative price $\left(D p_{i t}-D P_{t}\right), \mathrm{t}=1, \ldots, 41$, for all commodities are plotted in Figure 2. As can be seen, the points are mostly scattered around a negatively sloping line. Figure 3 plots the pooled data over the eight commodities and it also shows a similar pattern. The reason behind such an observation is that when the relative price of a commodity increases, there is a corresponding fall in its relative consumption. Under the assumption of unitary income elasticities, the slopes of the regression lines in Figures 2 and 3 can be interpreted as the estimate of the income flexibility, $\phi$, which is the reciprocal of the income elasticity of the marginal utility of income (see Selvanathan and Clements 1995). Table 4 presents the summary of the estimates of income flexibility of eight commodities and that of all commodities combined. As can be seen, all the estimates for $\phi$ are statistically significant and the estimate of $\phi$ for all goods combined is -0.69 and the mean value of $\phi$ is -0.59 are in agreement with a number of previous studies (for example see, Clements and Selvanathan 1994; Selvanathan and Selvanathan 2004; Wong, Selvanathan, and Selvanathan 2017).

Below, we investigate another important law in consumption economics, Engel's Law, which states that the budget share for food $\left(w_{\mathrm{Ft}}\right)$ falls

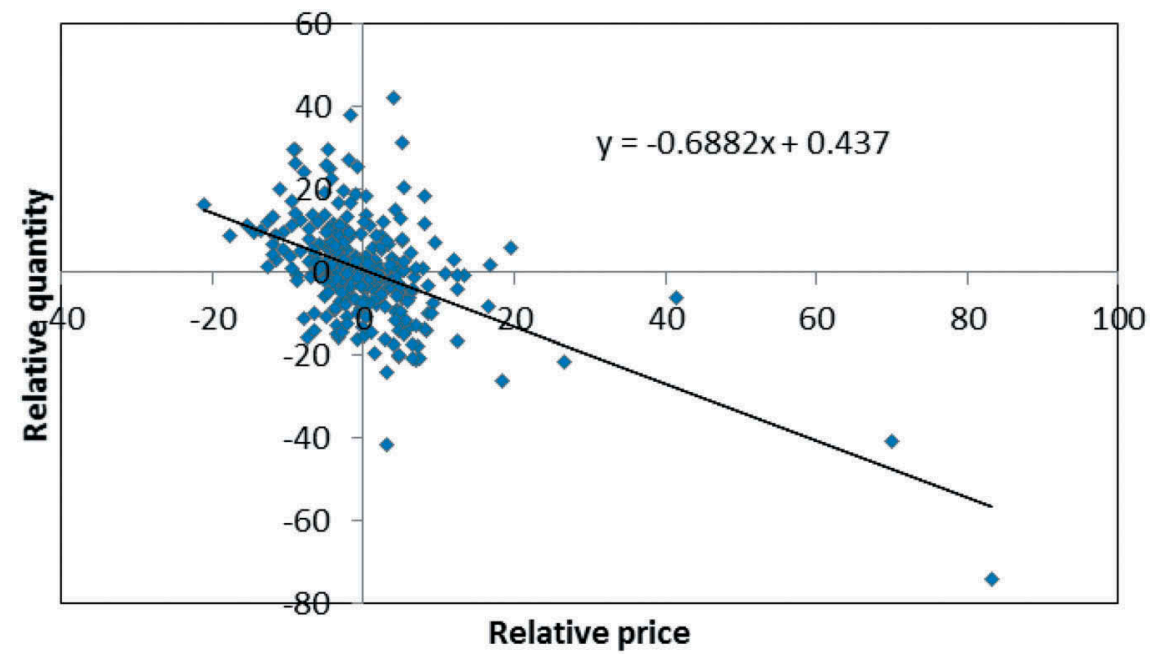

Figure 1. Quantity standard deviation vs price standard deviation, Sri Lanka, 1975-2016. 
Food
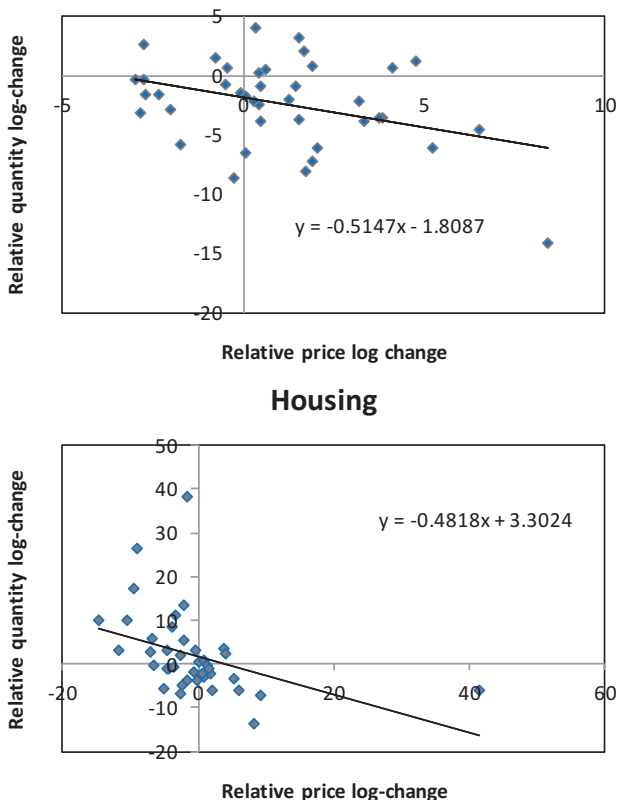

Medical care

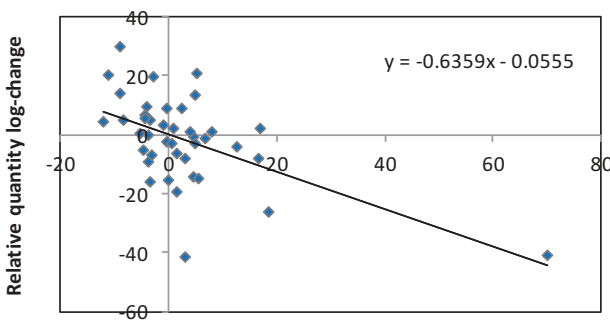

Relative price log-change

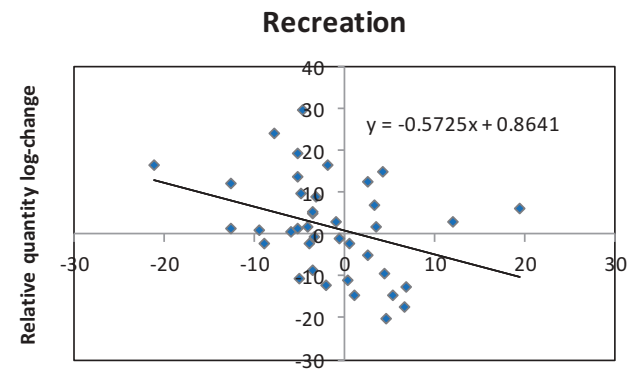

Realative price log-change
Clothing

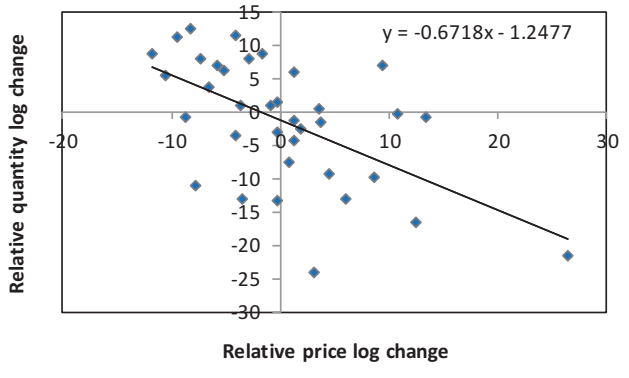

Durables

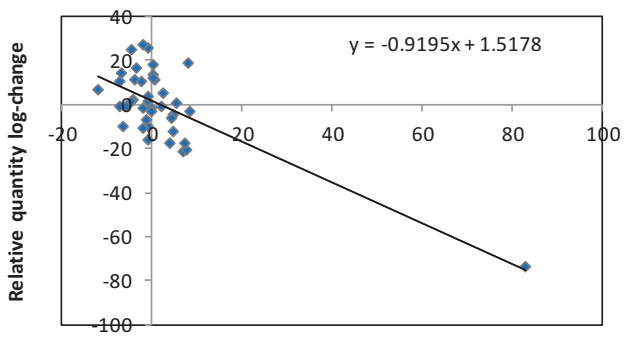

Relative price log-change

Transport

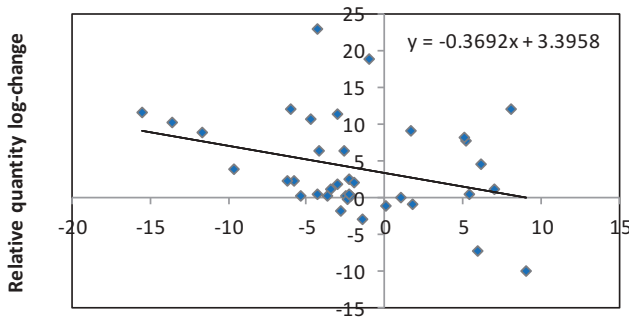

Relative price log-change

Miscelleneous

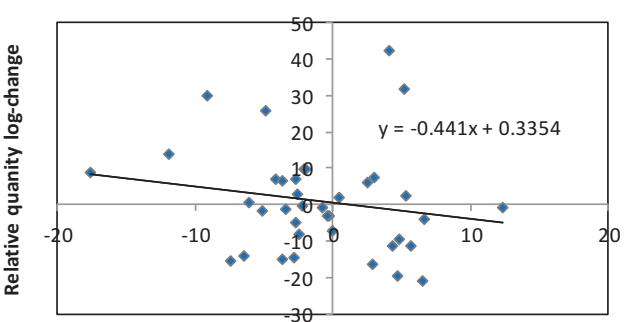

Relative price log-change

Figure 2. Relative consumption and relative prices, eight commodities, Sri Lanka, 1975-2016.

with increasing income $\left(M_{t}\right)$. In other words, that the income elasticity of demand for food is less than unity. This relationship can be written in a linear regression framework as the Working's (1943) model.

$$
w_{F t}=\alpha_{F}+\beta_{F} \ln M_{t}
$$

Figure 4 plots the food budget share against the logarithm of the per capita real consumption expenditure for Sri Lanka. As can be seen, the points are all scattered around a downward sloping line with slope, $\beta_{F}=-0.0561$. This means that when income increases by $1 \%$, the budget share for food will decline by $5.61 \%$, thus providing strong support for Engel's law. The estimated slope coefficient, $\beta_{F}$, can also be used to derive some preliminary estimates for income elasticity given by, $\eta_{F}=\left(1+\beta_{F} / \bar{w}_{F}\right)$, and marginal share, $\theta_{F}=\left(\beta_{F}+\bar{w}_{F}\right)$. The estimated coefficient $\left(\beta_{F}\right)$ and budget share for food $\left(\bar{w}_{F}\right)$ for Sri Lanka are 


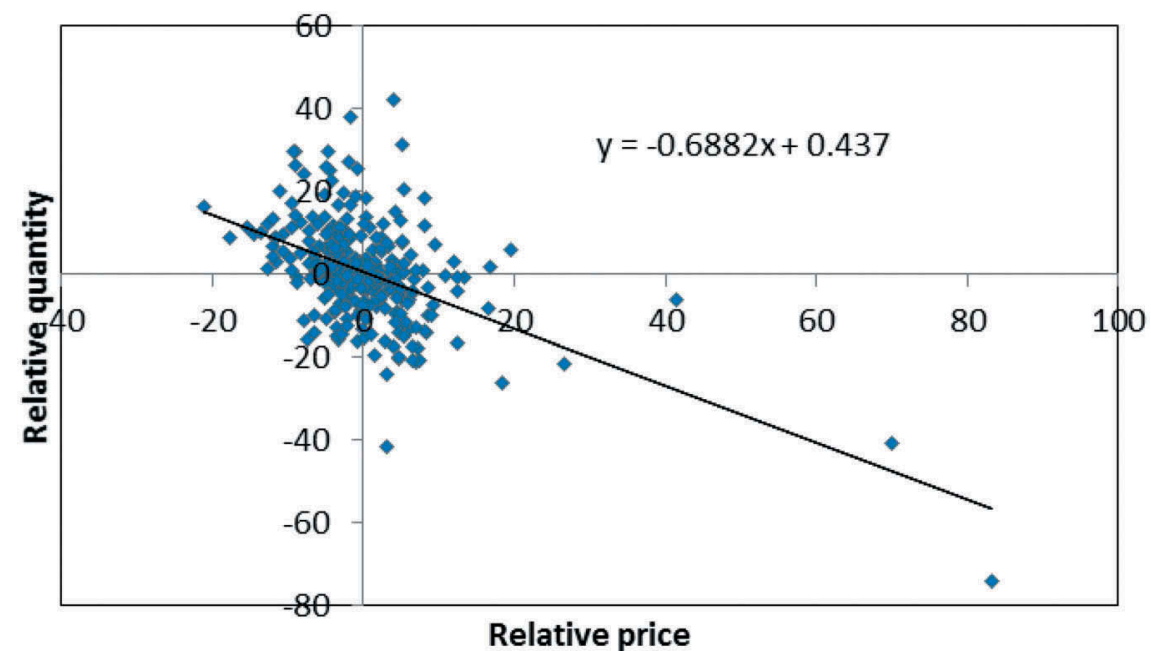

Figure 3. Relative consumption vs relative price, all goods, Sri Lanka 1975-2016.

Table 4. Slope estimates of the demand curve: income flexibility $(\phi)$, Sri Lanka, 1975-2016.

\begin{tabular}{lc}
\hline Commodity & Income flexibility \\
\hline Food & $-0.515(0.205)$ \\
Clothing & $-0.672(0.168)$ \\
Housing & $-0.482(0.249)$ \\
Durables & $-0.920(0.137)$ \\
Medical care & $-0.636(0.150)$ \\
Transport & $-0.369(0.183)$ \\
Recreation & $-0.573(0.253)$ \\
Miscellaneous & $-0.441(0.407)$ \\
All goods & $-0.688(0.064)$ \\
Mean & $-0.588(0.018)$ \\
\hline
\end{tabular}

Note: Standard errors are in parentheses.

-0.0561 and 0.536 , respectively. Therefore, the marginal share $\left(\theta_{F}\right)$ is calculated as 0.480 and the income elasticity $\left(\eta_{F}\right)$ is 0.895 . The income elasticity for food is less than one, which indicates that food is a necessity in Sri Lanka.

\section{Demand system estimation and testing hypotheses}

In terms of the differential demand systems in the system-wide approach, one of the most popularly utilised demand systems in applied demand analysis has been the Rotterdam demand system (Barten 1964; Theil 1965) and we use this demand system to analyse the consumption patterns of eight commodities in Sri Lanka. We first introduce the Rotterdam demand system to be used for estimation and then the demand theory hypotheses, homogeneity, symmetry and preference independence, which are to be tested.

The basic specification of the Rotterdam model for good $i$ takes form (see, for example, Theil 1980; Selvanathan and Clements 1995);

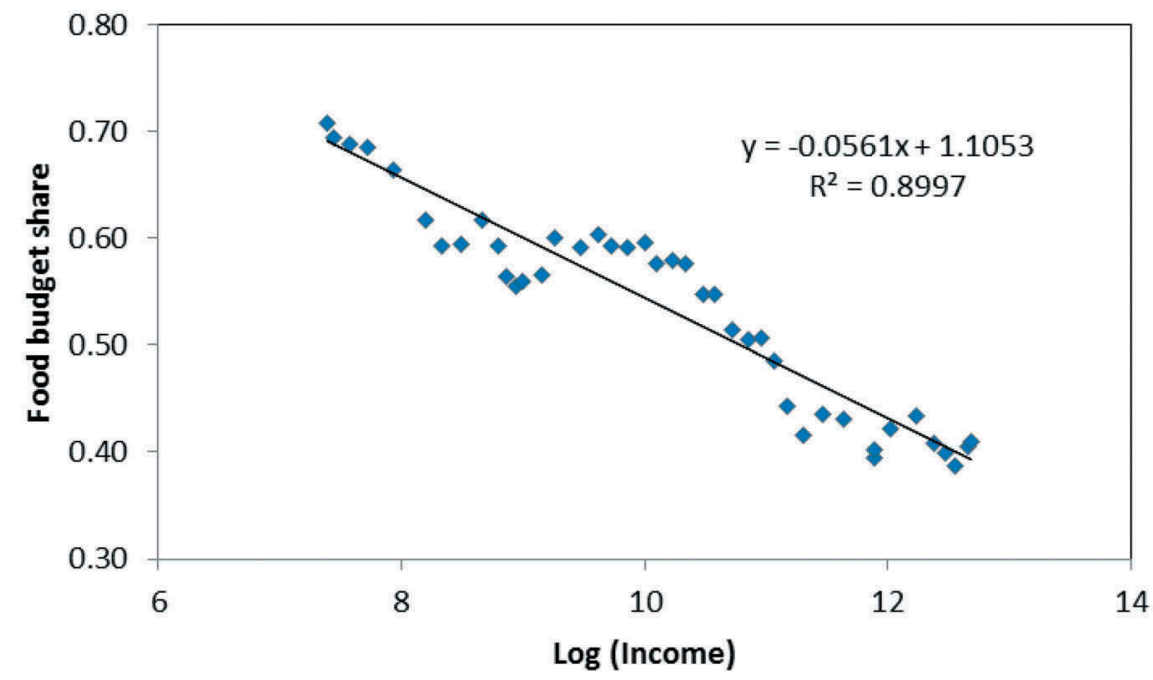

Figure 4. Food budget share vs the logarithm of income, Sri Lanka, 1975-2016. 


$$
\begin{aligned}
\bar{w}_{i t} D q_{i t} & =\alpha_{i}+\theta_{i} D Q_{t} \\
& +\sum_{j=1}^{n} \pi_{i j} D p_{j t}+\varepsilon_{i t} \quad i=1,2, \ldots, n
\end{aligned}
$$

where $\bar{w}_{i t}, D q_{i t}, D p_{j t}$ and $D Q_{\mathrm{t}}$ are defined as before, and $\alpha_{i}$ is the constant term of the $\mathrm{i}^{\text {th }}$ demand equation satisfying the adding up restriction $\sum_{i=1}^{n} \alpha_{i}=0$. The use of the constant term in the demand equations is to take into account any trendlike changes in tastes, etc. When income increases by one dollar, the marginal share $\theta_{i}$, measures how much of this increase is spent on commodity $i$. The coefficient $\pi_{i j}$ is the $(\mathrm{i}, \mathrm{j})^{\mathrm{th}}$ Slutsky price coefficient, which satisfies $\pi_{i j}=\pi_{j i}, \mathrm{j}=1,2, \ldots, n$. These price coefficients also satisfy the following constraints:

$$
\sum_{j=1}^{n} \pi_{i j}=0 \quad i=1,2, \ldots, n
$$

Constraint (2) reflects the homogeneity property of the demand system, which postulates that an equi-proportionate change in all prices has no effect on the demand for any good under the condition that real income is held constant. Accordingly, Equation (2) is known as demand homogeneity.

The Slutsky coefficients are symmetric in $\mathrm{i}$ and $\mathrm{j}$, that is

$$
\pi_{i j}=\pi_{j i} \quad i, j=1,2, \ldots, n
$$

which is known as Slutsky symmetry. This means that an increase in the price of any good $j$ will cause an increase in the compensated quantity demanded of $i$ equal to the increase in the compensated quantity demanded of $j$ caused by an increase in the price of $i$. In other words, because the commodity subscripts can be interchanged, and the substitution effects are symmetric in $i$ and $j$. Also, the Slutsky matrix $\left[\pi_{i j}\right]$ is symmetric and negative semi-definite with rank $(n-1)$.

The term $\varepsilon_{i t}$ is the disturbance term of the $i^{\text {th }}$ equation. It is assumed that the disturbance terms, $\varepsilon_{\mathrm{it}}, i=1, \ldots, n$, are serially independent and normally distributed with zero means and have a constant contemporaneous covariance matrix, such that $\operatorname{Cov}\left(\varepsilon_{\mathrm{it}}, \varepsilon_{\mathrm{js}}\right)=0$ for $\mathrm{t} \neq \mathrm{s}$ and $\operatorname{Cov}\left(\varepsilon_{\mathrm{it}}, \varepsilon_{\mathrm{jt}}\right)=\sigma_{i j}(i, j=1$, $\ldots, n)$. The income and price elasticities implied by the demand system given by Equation (1) are

$$
\eta_{i t}=\frac{\theta_{i}}{\bar{w}_{i t}} \quad \text { and } \quad \eta_{i j t}=\frac{\pi_{i j}}{\bar{w}_{i t}}
$$

If the income elasticity of good $i$ is less (greater) than one, the good $i$ is classified as a necessity (luxury). We calculate these elasticities at sample means of the budget shares as

$$
\bar{\eta}_{i}=\frac{\theta_{i}}{\bar{w}_{i}} \quad \text { and } \quad \bar{\eta}_{i j}=\frac{\pi_{i j}}{\bar{w}_{i}}
$$

where $\bar{w}_{i}=(1 / T) \sum_{i=1}^{T} \bar{w}_{i t}$.

Because the variables used to estimate the demand system are time series variables, before estimation, it is desirable to investigate whether the variables to be used in the demand system estimation are stationary to avoid any spurious results. We use the Augmented Dicky-Fuller unit root test (Dickey and Fuller 1979, 1981) for this purpose. The test results are presented in Table 5. As can be seen, since all the $p$-values (except the one for the $D p_{i t}$ corresponding to recreation) are less than the level of significance $\alpha=0.05$ and the $p$-value for recreation for $D p_{i t}$ is less than level of significance $\alpha=0.10$, we can safely conclude that all the variables to be used in the demand system are stationary.

Demand Analysis Package, DAP2000 (Yang, Clements, and Chen 2003) and DEMMOD-3 (Barten et al. 1989) program are used to estimate the Rotterdam demand model. First, the demand system is estimated in unrestricted form to test the demand theory hypothesis - homogeneity and symmetry. The conventional methods to test the homogeneity, symmetry, and the joint test for both homogeneity and symmetry include the Wald test, likelihood ratio test, and Lagrange multiplier test. However, simulation experiments have shown that these tests have considerable bias toward rejection of

Table 5. Stationarity test results of the demand system variables.

\begin{tabular}{lccccc}
\hline & \multicolumn{2}{c}{$\bar{w}_{i t} D q_{i t}$} & & \multicolumn{2}{c}{$D p_{i t}$} \\
\cline { 2 - 3 } \cline { 5 - 6 } Commodity $\mathrm{i}$ & Test Statistics & p-value & & Test Statistics & p-value \\
\hline Food & -5.054 & 0.000 & & -3.583 & 0.006 \\
Clothing & -4.013 & 0.001 & & -5.493 & 0.000 \\
Housing & -4.303 & 0.000 & & -3.868 & 0.023 \\
Durables & -3.901 & 0.002 & & -4.313 & 0.004 \\
Medical care & -4.172 & 0.007 & & -4.038 & 0.001 \\
Transport & -4.118 & 0.009 & & -4.794 & 0.001 \\
Recreation & -5.845 & 0.000 & & -2.673 & $0.078^{*}$ \\
Miscellaneous & -4.489 & 0.002 & & -3.470 & 0.008 \\
$D Q_{t}$ & -3.622 & 0.005 & & \\
\hline
\end{tabular}

*Significant at $10 \%$ level. 
the null hypothesis, in particular when they are applied to large demand systems with relatively few observations (Laitinen 1978; Meisner 1979, Bera, Byron, and Jarque 1981; Selvanathan 1993; Selvanathan and Clements 1995; Balcombe and Davis 1996). Therefore, we have used the finitesample test introduced by Laitinen (1978) based on Hotelling's $T^{2}$ distribution, which is also a constant $[(n-1)(T-n-2) /(T-2 n)]$ multiple of the $F$ distribution with $n-1$ and $T-2 n$ degrees of freedom for testing demand homogeneity. The value of the Hotelling's $T^{2}$ test statistic is 17.77 with a critical value of $8.68 \times \mathrm{F}_{0.05}(7,25)=8.68 \times 2.40=$ 20.83 at the $5 \%$ level of significance. Therefore, the data support the demand homogeneity hypothesis.

For testing symmetry, we use an asymptotic $\chi^{2}$ test with $q=(1 / 2)(n-1)(n-2)$ degrees of freedom (see Theil 1971, for details) because no finitesample test is available. The value of the test static for testing symmetry is 34.2 with critical values, $\chi_{0.05,21}^{2}=32.67$ and $\chi_{0.01,21}^{2}=38.9$. Therefore, we are unable to reject Slutsky symmetry at the $1 \%$ level of significance.

Now, we test for the preference independent utility structure among Sri Lankan consumers. When consumers' tastes can be described by means of a utility function, which can be written as the sum of $n$ subutility functions, each involving one good only, then tastes are said to exhibit preference independence or additive preferences. Preference independence also means that the marginal utility of good $i$ is independent of the consumption of good $j, i \neq j$.

Under preference independence, the Slutsky coefficients take the form (see, for example Selvanathan and Selvanathan 1994):

$$
\pi_{i j}=\phi \theta_{i}\left(\delta_{i j}-\theta_{j}\right) \quad \mathrm{i}, \mathrm{j}=1,2, \ldots, \mathrm{n}
$$

where $\phi$ is the income flexibility (the reciprocal of the income elasticity of the marginal utility of income) and $\delta_{i j}$ is the Kronecker delta. Substituting (5) for $\pi_{i j}$ in Equation (1), the preference independence version of Equation (1) can be written as

$$
\begin{gathered}
\bar{w}_{i t} D q_{i t}=\alpha_{i}+\theta_{i} D Q_{t} \\
+\phi \theta_{i}\left[D p_{i t}-\sum_{j=1}^{n} \theta_{j} D p_{j t}\right]+\varepsilon_{i t} \\
i=1, \ldots ., n
\end{gathered}
$$

Because the demand system given in Equation (6) is non-linear in the parameters, we estimate Equation (6) by maximum likelihood (ML) and use the Monte-Carlo simulation test proposed by Selvanathan (1987) to test the assumption of preference independence. Under this approach, using 999 simulations, if the rank of the test statistic is between 991 and 999, the null hypothesis of preference independence is rejected at the $1 \%$ level of significance. The rank of the data based value of the test statistic is found to be 972 . This means that at the $1 \%$ level of significance, the preference independence structure of the utility function cannot be rejected for Sri Lankan consumers. Therefore, we use the preference independence version of the Rotterdam model to compute demand elasticities.

\section{Estimation results and implied demand elasticities}

Table 6 presents the estimation results from the Rotterdam model under preference independence given by Equation (6). As can be seen, the constant term for food, clothing, durables, recreation, and miscellaneous are negative, while the constant term for other commodities are positive. This means that there is an autonomous trend out of food, clothing, durables, and miscellaneous into housing, medical care, transport, and recreation. As can be seen in column (3) of Table 6, the marginal shares for all commodities are positive and statistically significant implying that none of the eight commodities is inferior for Sri Lankan consumers. Further, food, transport, clothing, and housing have the highest marginal shares $(0.467$, $0.154,0.095$ and 0.074 , respectively). This means that if income increases by an additional rupee, Sri

Table 6. Estimation results under preference independence Sri Lanka, 1975-2016.

\begin{tabular}{lcc}
\hline $\begin{array}{l}\text { Item, i } \\
(1)\end{array}$ & $\begin{array}{c}\text { Constant }\left(a_{i} \times 100\right) \\
(2)\end{array}$ & $\begin{array}{r}\text { Income coefficient }\left(\theta_{i}\right) \\
(3)\end{array}$ \\
\hline Food & $-0.632(0.331)$ & $0.467(0.052)$ \\
Clothing & $-0.134(0.120)$ & $0.095(0.016)$ \\
Housing & $0.352(0.196)$ & $0.074(0.023)$ \\
Durables & $-0.062(0.099)$ & $0.069(0.010)$ \\
Medical care & $0.003(0.031)$ & $0.015(0.003)$ \\
Transport & $0.670(0.213)$ & $0.154(0.026)$ \\
Recreation & $-0.120(0.151)$ & $0.061(0.019)$ \\
Miscellaneous & $-0.078(0.111)$ & $0.065(0.011)$ \\
Income flexibility $(\phi)$ & & $-0.628(0.077)$ \\
\hline
\end{tabular}

Note: Standard errors are in parentheses. 
Table 7. Income and price elasticities from the Rotterdam demand system under preference independence.

\begin{tabular}{|c|c|c|c|c|c|c|c|c|c|}
\hline \multirow[b]{2}{*}{$\begin{array}{l}\text { Commodity } \\
\text { (1) }\end{array}$} & \multirow[b]{2}{*}{$\begin{array}{l}\text { Income elasticity } \\
\text { (2) }\end{array}$} & \multicolumn{8}{|c|}{ Price elasticities } \\
\hline & & $\begin{array}{l}\text { Food } \\
\text { (3) }\end{array}$ & $\begin{array}{l}\text { Clothing } \\
\text { (4) }\end{array}$ & $\begin{array}{l}\text { Housing } \\
\text { (5) }\end{array}$ & $\begin{array}{c}\text { Durables } \\
\text { (6) }\end{array}$ & $\begin{array}{c}\text { Medical care } \\
\text { (7) }\end{array}$ & $\begin{array}{c}\text { Transport } \\
\text { (8) }\end{array}$ & $\begin{array}{l}\text { Recreation } \\
\text { (9) }\end{array}$ & $\begin{array}{c}\text { Miscellaneous } \\
\text { (10) }\end{array}$ \\
\hline Food & 0.87 & -0.29 & 0.05 & 0.04 & 0.04 & 0.01 & 0.09 & 0.03 & 0.04 \\
\hline Clothing & 1.32 & 0.39 & -0.75 & 0.06 & 0.06 & 0.01 & 0.13 & 0.05 & 0.05 \\
\hline Housing & 0.93 & 0.27 & 0.06 & -0.54 & 0.04 & 0.01 & 0.09 & 0.04 & 0.04 \\
\hline Durables & 1.45 & 0.42 & 0.09 & 0.07 & -0.84 & 0.01 & 0.14 & 0.06 & 0.06 \\
\hline Medical care & 0.87 & 0.26 & 0.05 & 0.04 & 0.04 & -0.54 & 0.08 & 0.03 & 0.04 \\
\hline Transport & 0.90 & 0.26 & 0.05 & 0.04 & 0.04 & 0.01 & -0.48 & 0.03 & 0.04 \\
\hline Recreation & 1.70 & 0.50 & 0.10 & 0.08 & 0.07 & 0.02 & 0.17 & -1.00 & 0.07 \\
\hline Miscellaneous & 1.61 & 0.47 & 0.10 & 0.07 & 0.07 & 0.02 & 0.16 & 0.06 & -0.94 \\
\hline
\end{tabular}

Lankan consumers will spend 47 cents for food, 15 cents for transport, 9.5 cents for clothing, and 7.4 cents for housing.

Table 7 presents the implied income and price elasticities given by the Preference Independence version of Rotterdam model. Looking at the income elasticities, food (0.87), housing (0.93), medical care (0.87), and transport (0.90) have income elasticities less than one, indicating that these four commodities are necessities. Clothing (1.32), durables (1.45), and recreation (1.70) have income elasticities greater than one, thus, indicating that these three commodities are luxuries. Among all commodities, durables and recreation, with the highest income elasticities, are the commodities most sensitive to income changes.

All the own-price elasticities are negative, as expected. The estimated own-price elasticities for food (-0.29), clothing (-0.75), housing $(-0.54)$, durable $(-0.84)$, medical care $(-0.54)$, transport $(-0.48)$ and miscellaneous $(-0.94)$ are all less than one in absolute value. Thus, demand for all of these commodities is price inelastic. However, recreation $(-1.00)$, with unitary price elasticity in absolute value, is price elastic.

\section{Decomposition in the changes of consumption patterns in Sri Lanka}

In this section, we use the estimation results presented in Section 4 to decompose the changes in consumption patterns of eight broad commodities into various components. We present two applications. The first application shows the decomposition of the growth in consumption expenditure of eight commodities in terms of autonomous trend, income, own price, and cross prices. The second application demonstrates how the changes in budget shares of eight commodities can be decomposed in terms of autonomous trend, income, own-price, and cross-prices.

\section{Growth in consumption expenditure and its components}

We divide both sides of the demand system in Equation (1) by the budget share $\bar{w}_{i t}$ to give

$$
\begin{aligned}
D q_{i t} & =\alpha_{i t}^{*}+\eta_{i} D Q_{t}+\eta_{i i} D p_{i t} \\
& +\sum_{j(\neq i)=1}^{n} \eta_{i j} D p_{j t}+\varepsilon_{i t}^{*} \\
& i=1, \ldots, n ; t=1, \ldots, T
\end{aligned}
$$

where $\alpha_{i t}^{*}=\alpha_{i} / \bar{w}_{i t}$ is the autonomous trend in consumption of item $\mathrm{i}$ and $\eta_{i}$ and $\eta_{i j}$ are income and price elasticities. Therefore, growth in consumption of item i $\left(D q_{i t}\right)$ in each year can be decomposed into the following five components, namely, (1) Autonomous trend component $\left(\alpha_{i t}^{*}\right)$; (2) Income component $\left(\eta_{i} D Q_{t}\right)$; (3) Ownprice component $\left(\eta_{i i} D p_{i t}\right)$; (4) Cross-price component $\left(\sum_{j(\neq i)=1}^{8} \eta_{i j} D p_{j t}\right) ; \quad$ and $\quad$ (5) Residual $\operatorname{component}\left(\varepsilon_{i t}^{*}\right)$.

Table 8 presents the decomposition of $D q_{i t}$ into the five components at sample means for the eight commodities. As can be seen, Column 2 shows quantity demanded for each commodity group has increased with different average annual growth rates. The income effect is positive in all cases, because all commodities were found to be normal goods. The numbers in the food row indicate that, on average, the total growth in food consumption expenditure has increased only at a rate of $1.97 \%$ per annum. This 
Table 8. Decomposition of change in consumption of eight commodities, Sri Lanka, 1975-2016 (at sample means).

\begin{tabular}{|c|c|c|c|c|c|c|}
\hline \multirow[b]{2}{*}{$\begin{array}{l}\text { Commodity i } \\
\text { (1) }\end{array}$} & \multirow[b]{2}{*}{$\begin{array}{c}\text { Total growth }\left(D \bar{q}_{i}\right) \\
\text { (2) }\end{array}$} & \multicolumn{5}{|c|}{ Components of growth in the consumption of item i } \\
\hline & & $\begin{array}{l}\text { Autonomous trend } \\
\text { (3) }\end{array}$ & $\begin{array}{l}\text { Income } \\
\text { (4) }\end{array}$ & $\begin{array}{l}\text { Own-price } \\
\text { (5) }\end{array}$ & $\begin{array}{c}\text { Cross-price } \\
\text { (6) }\end{array}$ & $\begin{array}{l}\text { Residual } \\
\text { (7) }\end{array}$ \\
\hline Food & 1.97 & -1.18 & 3.33 & -2.82 & 2.56 & -0.0012 \\
\hline Clothing & 4.17 & -1.87 & 5.03 & -5.74 & 6.98 & 0.0014 \\
\hline Housing & 7.55 & 4.40 & 3.55 & -4.45 & 5.01 & 0.0032 \\
\hline Durables & 2.74 & -1.30 & 5.52 & -9.25 & 7.63 & 0.0003 \\
\hline Medical & 2.18 & 0.18 & 3.32 & -6.26 & 4.92 & -0.0004 \\
\hline Transport & 8.13 & 3.90 & 3.42 & -4.04 & 4.42 & 0.0018 \\
\hline Recreation & 5.23 & -3.38 & 6.49 & -7.42 & 9.32 & -0.0043 \\
\hline Miscellaneous & 3.48 & -1.92 & 6.13 & -9.25 & 8.60 & -0.0100 \\
\hline
\end{tabular}

total growth is made up of the following: (1) autonomous trend, $-1.18 \%$, (2) income component, $3.33 \%$; (3) own-price component, $-2.82 \%$ (4) cross-price component, $2.56 \%$, and the (5) residual component, $-0.0012 \%$. The two components involving the ownand cross-prices are similar in magnitude but of opposite sign, thus cancelling out each other. The strong positive income component and a strong but negative autonomous trend component result in a positive but small overall growth in food consumption expenditure. For housing, positive autonomous trend, income and cross-price effect has resulted in considerable growth in housing consumption. Similarly for transport, the three strong positive components are: autonomous trend, cross-price, and income. These components have resulted in a big positive growth $(8.13 \%)$ in consumption expenditure for transport.

$$
\begin{aligned}
\Delta w_{i t}= & \bar{w}_{i t} D q_{i t}+\bar{w}_{i t}\left(D p_{i t}-D P_{t}\right) \\
& -\bar{w}_{i t} D Q_{t}+o_{3} \\
& i=1, \ldots, n ; t=1, \ldots, T
\end{aligned}
$$

where $\Delta w_{i t}=\left(w_{i t}-w_{i, t-1}\right) ; \quad D Q_{t}+D P_{t}=D M_{t}$ and $o_{3}$ is a reminder term of the third degree (see Theil 1975-76, 37-40 and 215). If we substitute $\bar{w}_{i t} D q_{i t}$ from Equations (1) and (8) becomes

$$
\begin{gathered}
\Delta w_{i t}=\alpha_{i}+\left(\theta_{i}-\bar{w}_{i t}\right) D Q_{t}+\pi_{i i} D p_{i t}+\sum_{j(\neq i)=1}^{8} \pi_{i j} D p_{j t} \\
+\bar{w}_{i t}\left(D p_{i t}-D P_{t}\right)+o_{3}+\varepsilon_{i t}, \\
\quad i=1, \ldots, n ; t=1, \ldots, T .
\end{gathered}
$$

where $\pi_{i j}=\phi \theta_{i}\left(\delta_{i j}-\theta_{j}\right)$.

Equation (9) shows that

change in budget share of item $i=$ autonomous trend component, $\alpha_{i}$

$$
\begin{aligned}
& + \text { income component, }\left(\theta_{i}-\bar{w}_{i t}\right) D Q_{t} \\
& + \text { own - price components, } \pi_{i i} D p_{i t} \\
& + \text { cross - price component, } \sum_{j(\neq i)=1}^{8} \pi_{i j} D p_{j t} \\
& + \text { direct relative price component, } \bar{w}_{i t}\left(D p_{i t}-D P t\right) \\
& + \text { the residual component. }
\end{aligned}
$$

On average, there is an autonomous trend out of food, clothing, durables, recreation, and miscellaneous and into housing, medical, and transport.

\section{Decomposition in the changes in the budget shares}

In finite changes, the budget share, $w_{i t}=p_{i t} q_{i t} / M_{t}$, can be expressed as (see Clements and Johnson 1983)
The estimated values of these components at sample means are presented in Table 9. Looking at the first row of the table, on average, the budget share of food has declined by $0.73 \%$ per annum. The major contributors to this fall are the shift in consumer preferences against food $(-0.632 \%)$ and its increased own price $(-1.507 \%)$. An increase in income has a negative impact on the changes in food budget shares supporting Engel's law as explained in Section 2. On average, 
Table 9. Decomposition of changes in budget shares of eight commodities, Sri Lanka, 1975-2016 (at sample means).

\begin{tabular}{|c|c|c|c|c|c|c|c|c|c|c|c|c|c|}
\hline \multirow[b]{3}{*}{$\begin{array}{l}\text { Commodity i } \\
\text { (1) }\end{array}$} & \multirow{3}{*}{$\begin{array}{c}\text { Change in the budget } \\
\text { share } \Delta \mathrm{w}_{\mathrm{i}} \\
\text { (2) }\end{array}$} & \multicolumn{12}{|c|}{ Components of $\Delta \mathrm{w}_{\mathrm{i}} \times 100$} \\
\hline & & \multirow[b]{2}{*}{$\begin{array}{l}\text { Trend } \\
\text { (3) }\end{array}$} & \multirow[b]{2}{*}{$\begin{array}{c}\text { Income } \\
(4)\end{array}$} & \multicolumn{8}{|c|}{ Price substitution } & \multirow[b]{2}{*}{$\begin{array}{c}\text { Direct relative price } \\
\text { (13) }\end{array}$} & \multirow[b]{2}{*}{$\begin{array}{l}\text { Residuals } \\
\text { (14) }\end{array}$} \\
\hline & & & & $\begin{array}{l}\text { Food } \\
(5)\end{array}$ & $\begin{array}{l}\text { Clothing } \\
\text { (6) }\end{array}$ & $\begin{array}{l}\text { Housing } \\
\text { (7) }\end{array}$ & $\begin{array}{l}\text { Durables } \\
\text { (8) }\end{array}$ & $\begin{array}{l}\text { Medical } \\
\quad(9)\end{array}$ & $\begin{array}{c}\text { Transport } \\
\text { (10) }\end{array}$ & $\begin{array}{l}\text { Recreation } \\
\text { (11) }\end{array}$ & $\begin{array}{l}\text { Miscellaneous } \\
\text { (12) }\end{array}$ & & \\
\hline Food & -0.726 & -0.632 & -0.003 & -1.507 & 0.212 & 0.178 & 0.223 & 0.050 & 0.385 & 0.132 & 0.188 & 0.279 & -0.00065 \\
\hline Clothing & -0.066 & -0.134 & 0.001 & 0.268 & -0.412 & 0.036 & 0.045 & 0.010 & 0.078 & 0.027 & 0.038 & -0.105 & 0.00010 \\
\hline Housing & 0.258 & 0.352 & 0.000 & 0.209 & 0.034 & -0.354 & 0.004 & 0.008 & 0.061 & 0.021 & 0.030 & -0.071 & 0.00026 \\
\hline Durables & 0.028 & -0.062 & 0.001 & 0.196 & 0.003 & 0.027 & -0.444 & 0.007 & 0.057 & 0.020 & 0.028 & 0.087 & 0.00001 \\
\hline Medical & 0.015 & 0.003 & 0.000 & 0.042 & 0.007 & 0.006 & 0.007 & -0.106 & 0.012 & 0.004 & 0.006 & 0.043 & -0.00001 \\
\hline Transport & 0.486 & 0.670 & -0.001 & 0.437 & 0.070 & 0.059 & 0.074 & 0.017 & -0.697 & 0.043 & 0.062 & -0.107 & 0.00030 \\
\hline Recreation & -0.009 & -0.120 & 0.001 & 0.171 & 0.028 & 0.023 & 0.029 & 0.007 & 0.050 & -0.265 & 0.024 & -0.061 & -0.00015 \\
\hline Miscellaneous & 0.014 & -0.078 & 0.001 & 0.185 & 0.030 & 0.025 & 0.031 & 0.007 & 0.054 & 0.018 & -0.376 & 0.028 & -0.00040 \\
\hline
\end{tabular}

the budget share of transport has increased by $0.486 \%$ per annum. The major contribution for this increase has come from the positive shift in consumer preferences $(0.670 \%)$ and price substitution of food $(0.437 \%)$. Budget share for housing has also increased by $0.258 \%$ per annum and the major contribution for this increase also comes from the positive change in consumer preferences $(0.352 \%)$ and price substitution on food $(0.209 \%)$.

\section{Simulation of consumption expenditure}

Now we simulate consumption expenditure for the eight commodities under different scenarios, to isolate the key factors that are responsible for the growth changes in consumption expenditure of different commodities in Sri Lanka. To perform these applications, we use the coefficient estimates and demand elasticities presented in Tables 6 and 7, together with the consumption expenditure and price data. It is an interesting policy issue to investigate what happens to the consumption of eight commodities, for example: (a) if consumer preferences did not change (that is, each constant term in the demand equation is equal to 0 ), (b) if income does not grow (that is, $D Q_{t}^{s}=0$ for any period $\mathrm{t}$ ); and (c) if income grew, for example, at a rate of $1 \%$ per annum (that is, $D Q_{t}^{s}=1 \%$ for any period $\mathrm{t}$ ).

\section{What if consumer preferences did not change?}

If we divide both sides of demand Equation (1) by the budget share $\bar{w}_{i t}$, the demand equation takes the form

$$
\begin{array}{r}
D q_{i t}=\alpha_{i t}^{*}+\eta_{i} D Q_{t}+\sum_{j=1}^{8} \eta_{i j} D p_{j t}+\varepsilon_{i t}^{*} \\
i=1, \ldots, n ; t=1, \ldots, T
\end{array}
$$

If the simulated consumption log-change $D q_{i t}^{s}$ corresponding to scenario (a) that there is no change in consumer preference, then

$$
\begin{array}{r}
D q_{i t}^{s}=0+\eta_{i} D Q_{t}+\sum_{j=1}^{8} \eta_{i j} D p_{j t}+\varepsilon_{i t}^{*} \\
i=1, \ldots, n ; t=1, \ldots, T
\end{array}
$$

Therefore, from Equations (11) and (12), we get

$$
D q_{i t}^{s}=D q_{i t}-\alpha_{i t}^{*} \quad i=1, \ldots, n ; t=1, \ldots, T
$$

Next, using Equation (13), we calculate the simulated consumption expenditure by converting changes to levels.

$$
\begin{gathered}
q_{i t}^{s}=q_{i t-1}^{s} \exp \left(D q_{i t}^{s}\right) \quad \text { with } q_{i, 1975}^{s}=q_{i, 1975,} \\
i=1, \ldots, n ; t=1, \ldots, T
\end{gathered}
$$

To obtain the simulated constant price expenditure in period t, we use Equation (14) and the constant price expenditure in period $t-1$. The simulated consumption expenditure for eight commodities under the condition of no change in preference are presented in Table 10. For comparison, the actual consumption expenditure is also presented in columns (2)-(9) of the same table. As can be seen, the simulated per capita consumption expenditure of food, clothing, housing, durables, medical care, transport, recreation, and miscellaneous for the year 2016 are Rs.2581.08, Rs.669.28, Rs.1629.36, Rs.158.42, Rs.55.62, Rs.2434.09, Rs.447.64 and Rs.253.82, respectively. Accordingly, in 2016, the shift in 


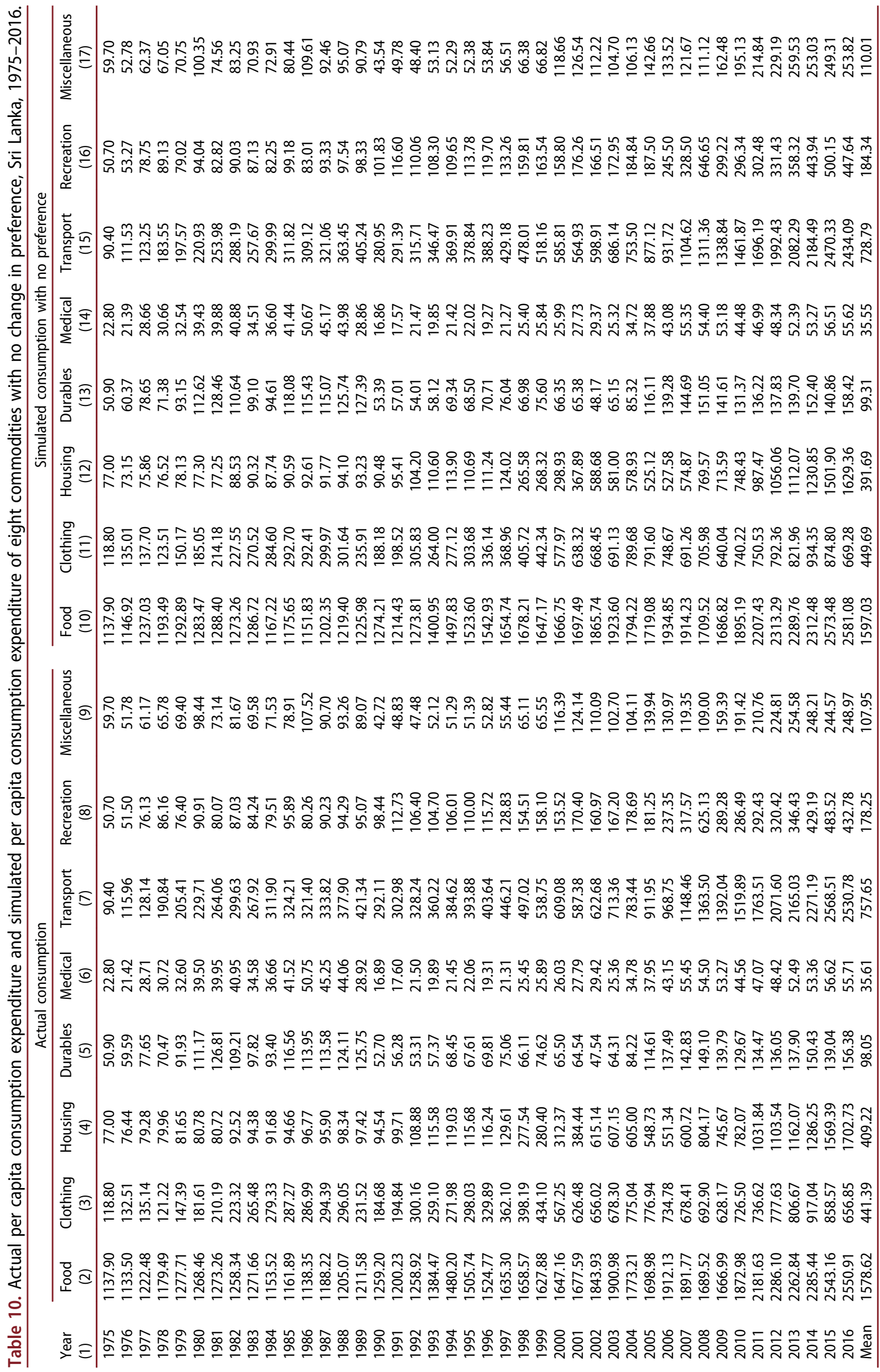


consumer preferences resulted in consumption expenditure of food to be (2581.08-2550.91) $\times 100 /$ $2581.08=1.17 \%$ higher than otherwise. Similarly, clothing would be $1.86 \%$, durables $1.29 \%$, recreation $3.32 \%$, and miscellaneous $1.91 \%$ lower than otherwise, and housing would be $4.50 \%$, medical care $0.17 \%$, and transport $3.97 \%$ higher than otherwise.

\section{What if income does not grow?}

If the simulated consumption log-change $\left(D q_{i t}^{s}\right)$ corresponded to the scenario (b) of no change in income (that is, $D Q_{t}^{s}=0$ ) is

$$
\begin{aligned}
D q_{i t}^{s} & =\alpha_{i t}^{*}+0 \\
& +\sum_{j=1}^{8} \eta_{i j} D p_{j t}+\varepsilon_{i t}^{*} \quad i=1, \ldots, n ; t=1, \ldots, T
\end{aligned}
$$

Therefore, from Equations (11) and (15), we get

$$
D q_{i t}^{s}=D q_{i t}-\eta_{i} D Q_{t} \quad i=1, \ldots, n ; t=1, \ldots, T
$$

We evaluate the simulated consumption as before, using Equations (14) and (16).

Columns (10)-(17) of Table 11 present the simulated consumption expenditure with zero income growth. As can be seen that the simulated per capita consumption expenditure of food, clothing, housing, durables, medical care, transport, recreation and miscellaneous for the year 2016 are Rs.2467.14, Rs.624.61, Rs.1643.23, Rs.147.98, Rs.53.89, Rs.2445.71, Rs.405.55 and Rs.234.18, respectively. Accordingly, zero growth in income would cause food consumption to be about $[(2467.14-2550.91) \times 100 / 2467.14=] 3.40 \%$ lower than otherwise. Similarly, clothing would be $5.16 \%$, housing $3.62 \%$, durables $5.68 \%$, medical care $3.37 \%$, transport $3.48 \%$, recreation $6.71 \%$ and miscellaneous $6.32 \%$ lower than otherwise.

\section{What if total income grew at a rate of $1 \%$ per annum?}

If the simulated consumption log-change $D q_{i t}^{s}$ corresponded to scenario (c) of a growth rate in income of $1 \%$ per annum (that is, $D Q_{t}^{s}=1$ ) is

$$
\begin{array}{r}
D q_{i t}^{s}=\alpha_{i t}^{*}+\eta_{i}(1)+\sum_{j=1}^{8} \eta_{i j} D p_{j t}+\varepsilon_{i t}^{*} \\
i=1, \ldots, n ; t=1, \ldots, T
\end{array}
$$

Therefore, from Equations (11) and (17), we get

$$
D q_{i t}^{s}=D q_{i t}+\eta_{i}\left(1-D Q_{t}\right), \quad i=1, \ldots, n ; t=1, \ldots, T
$$

We evaluate the simulated consumption, as before, using Equations (14) and (18). Columns (10)-(17) of Table 12 present the simulated consumption expenditure with $1 \%$ income growth. As can be seen, the simulated per capita consumption expenditure of food, clothing, housing, durables, medical care, transport, recreation, and miscellaneous for the year 2016 are Rs.5906.53, Rs.2333.49, Rs.4164.77, Rs.627.70, Rs.128.64, Rs.985.48, Rs.2219.98, and Rs.1165.72, respectively. Accordingly, in 2016, a $1 \%$ growth in income would have caused consumption expenditures on food to be $56.81 \%$ $[=(5906.53-2550.91) \times 100 / 5906.53]$, clothing $71.85 \%$, housing $59.12 \%$, durables $75.09 \%$, medical care $56.69 \%$, transport $57.72 \%$, recreation $80.51 \%$, and miscellaneous $78.64 \%$ higher than otherwise.

\section{Concluding comments}

In this paper, we have analysed the consumer demand in Sri Lanka during the period 1975-2016 considering eight commodities, namely food, clothing, housing, durables, medical care, transport, recreation, and miscellaneous. In addition to the estimation of income and price elasticities, we have given a special emphasis on decomposition analysis of changes in consumer demand and the simulation of consumption expenditure under various policy scenarios.

The analysis of price and consumption data has revealed that Sri Lankan consumers allocate more than half of their income on food and nearly $80 \%$ of their income on food, housing and, transport combined. More importantly, Sri Lankan consumption data supports the following empirical regularities: (1) Quantity variance systematically exceeds the price variance, (2) Consumption patterns support the Law of Demand, (3) Income Flexibility $(\phi)$ is an international constant and is around -0.5 , and (4) Budget share for food decreases when the consumer becomes more affluent (Engel's Law).

We used the well-known Rotterdam demand system to estimate the income and price elasticities of the eight commodities and tested the demand theory hypotheses, demand homogeneity, Slutsky symmetry, 


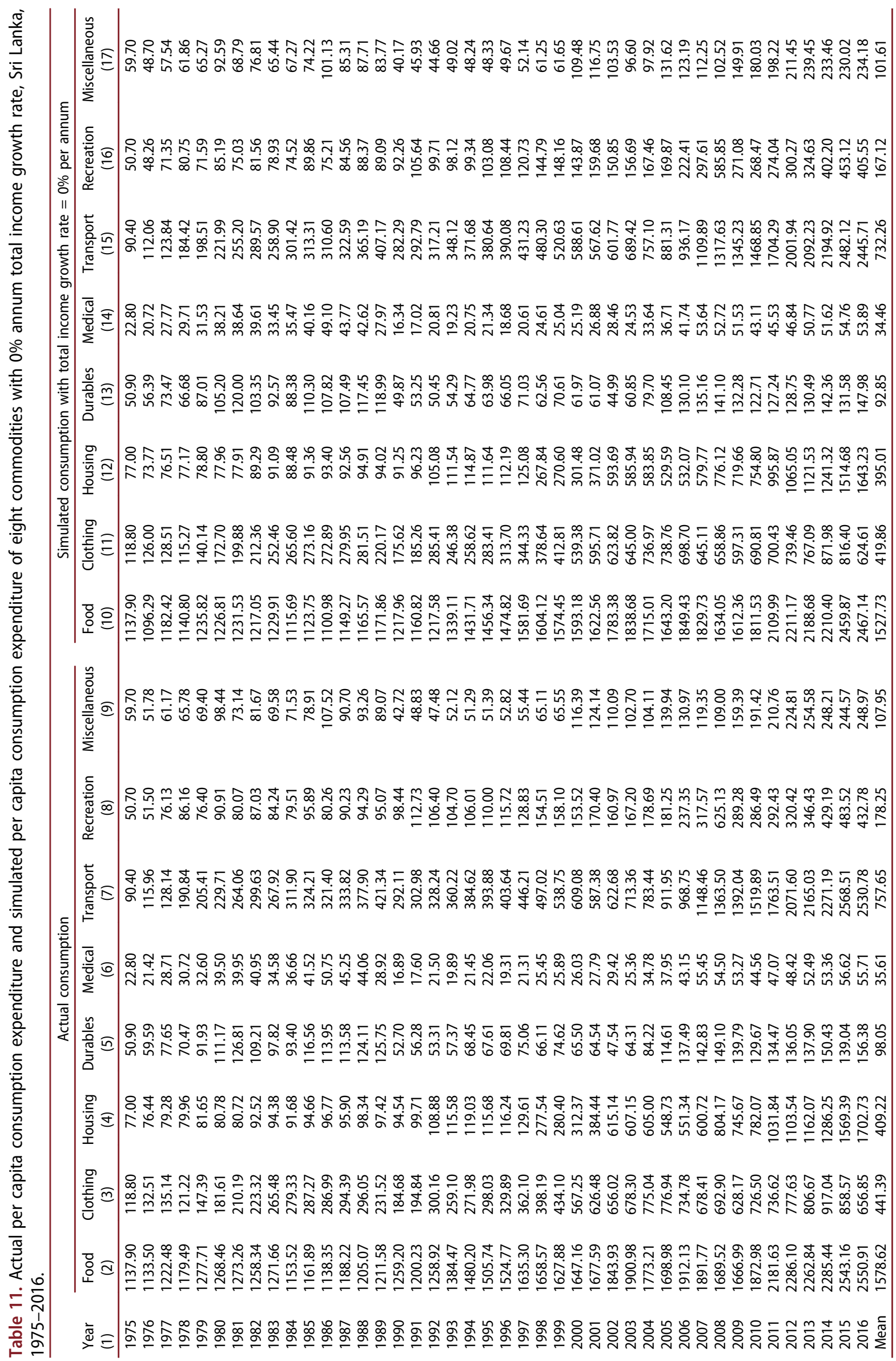




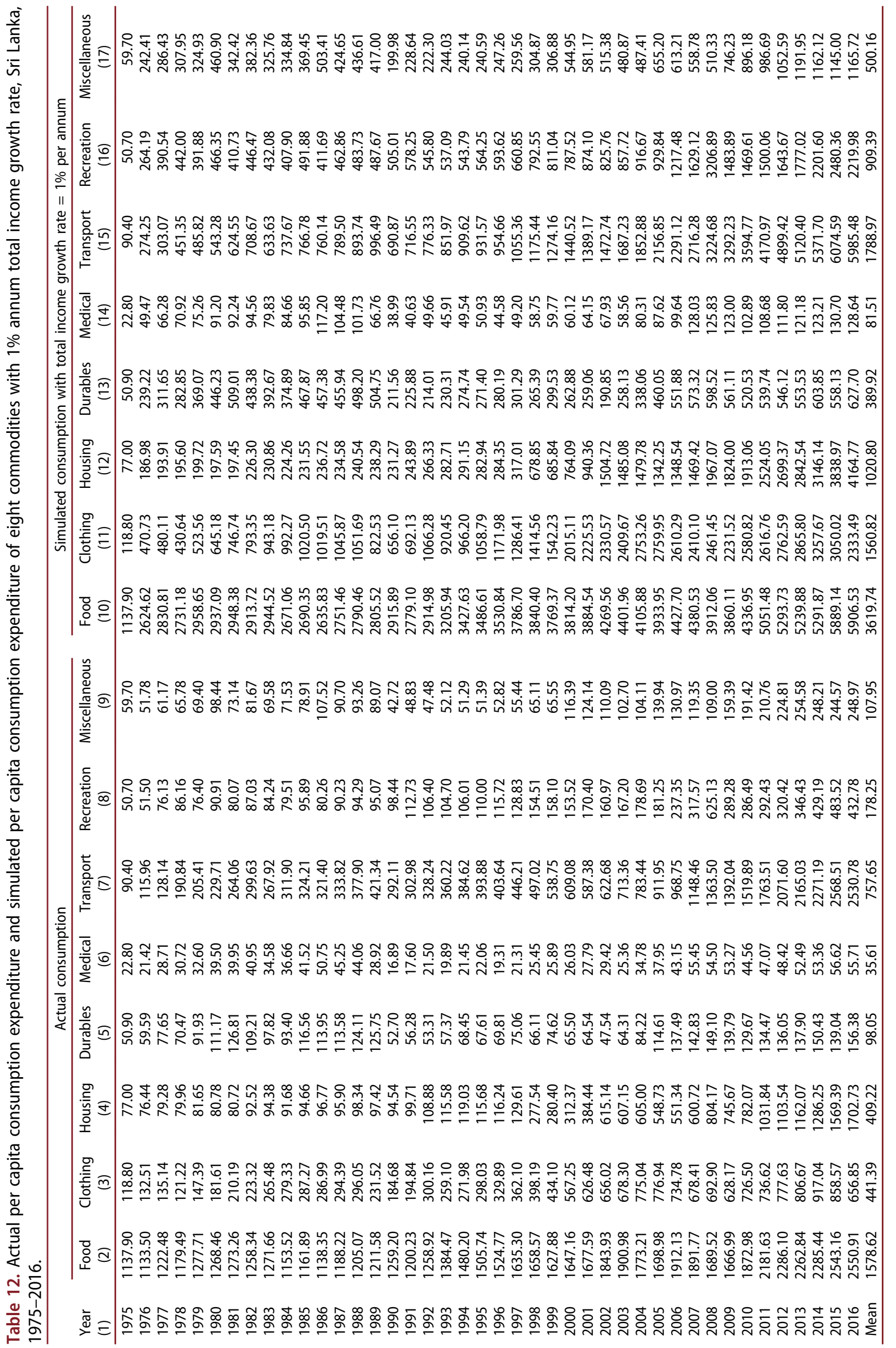


and preference independence, and found support for all three hypothesis with the Sri Lankan consumption data. Based on the estimated elasticities, food, housing, medical care, and transport are found to be necessities, while clothing, durables, and recreation are found to be luxury goods. In addition we also found that the demand for all commodities is price inelastic except for recreation.

Next, we decomposed the growth in consumption expenditure and change in budget shares of eight commodities into the effect of changes in consumer taste, income effect, own price effect, and cross price effect. Results of decomposition analysis can be used in policy issues because it shows the effect of simultaneous changes in prices, income, and tastes. Using the income and price elasticity estimates, we also simulated per capita consumption expenditure of eight commodities under various policy scenarios. Simulation results show that income growth has played a significant role in Sri Lankan consumption patterns.

\section{Acknowledgments}

The authors would like to thank the anonymous referees of this journal for their constructive comments and also thank the discussant and participants of the PhD Symposium in Economics 2017, Griffith University, Australia, for their valuable comments on an earlier version of this paper.

\section{Disclosure statement}

No potential conflict of interest was reported by the authors.

\section{ORCID}

Saroja Selvanathan (D) http://orcid.org/0000-0002-4129-1727

\section{References}

Balcombe, K. G., and J. R. Davis. 1996. “An Application of Cointegration Theory in the Estimation of the Almost Ideal Demand System for Food Consumption in Bulgaria.” Agricultural Economics 15 (1): 47-60.

Barten, A. P. 1964. "Consumer Demand Functions under Conditions of Almost Additive Preferences." Econometrica 32: 1-38.

Barten, A. P., L. Bettendorf, E. Meyermans, and P. Zonderman. 1989. Users' Guide to DEMMOD-3. Belgium: Kathlieke Universiteit Leuven.
Bera, A. K., R. P. Byron, and C. M. Jarque. 1981. "Further Evidence on Asymptotic Tests for Homogeneity and Symmetry in Large Demand Systems." Economics Letters 8 (2): 101-105.

Chen, D. L. 2001. World Consumption Economics. Singapore, London: World Scientific.

Clements, K. W. 1982. "Divisia Moments of Australian Consumption." Economics Letters 9 (1): 43-48.

Clements, K. W. 1983. "The Demand for Energy Used in Transport." Australian Journal of Management 8: 27-56.

Clements, K. W., and L. W. Johnson. 1983. "The Demand for Beer, Wine, and Spirits: A System-Wide Analysis." The Journal of Business 56 (3): 273-304.

Clements, K. W., and S. Selvanathan. 1994. "Understanding Consumption Patterns." Empirical Economics 19: 69-110.

Clements, K. W., Y. Wu, and J. Zhang. 2006. "Comparing International Consumption Patterns." Empirical Economics 31 (1): 1-30.

Deaton, A., and A. Case (1987). Analysis of Household Expenditures. Living Standards Measurement Study. LSMS Working Paper No. 28. Washington, DC: World Bank.

Dickey, D. A., and W. A. Fuller. 1979. "Distribution of the Estimators for Autoregressive Time Series with a Unit Root." Journal of the American Statistical Association 74: 427-431.

Dickey, D. A., and W. A. Fuller. 1981. "Likelihood Ratio Statistics for Autoregressive Time Series with a Unit Root." Econometrica 49: 1057-1072.

Dong, F. 2006. “The Outlook for Asian Dairy Markets: The Role of Demographics, Income, and Prices." Food Policy 31 (3): 260-271.

Edirisinghe, J. C. 2014. “Assessing the Demand for a Healthy Diet in Sri Lanka: The Almost Ideal Demand System with Infrequency of Purchase." Economic Research 2 (2): 23-41.

Heien, D. M., and C. R. Wessells. 1988. "The Demand for Dairy Products: Structure, Prediction, and Decomposition." American Journal of Agricultural Economics 70 (2): 219-228.

Karagiannis, G., and K. Velentzas. 1997. "Explaining Food Consumption Patterns in Greece." Journal of Agricultural Economics 48 (1-3): 83-92.

Karagiannis, G., and K. Velentzas. 2004. "Decomposition Analysis of Consumers' Demand Changes: An Application to Greek Consumption Data." Applied Economics 36 (5): 497-504.

Kottage, D. J. P. (1988). “An Analysis of Food Consumption Expenditures of Rural Households: A Case Study of Three Regions in Sri Lanka". Unpublished Master of Economics Thesis, University of New England.

Laitinen, K. 1978. "Why Is Demand Homogeneity So Often Rejected?" Economics Letters 1: 187-191.

Lokuge, L. D. M. N., and J. C. Edirisinghe. 2015. "Econometric Analysis of the Demand for Pulses in Sri Lanka: An Almost Ideal Estimation with a Censored Regression." Journal of Agriculture and Environment for International Development 109 (1): 41-53. 
Meisner, J. F. 1979. "The Sad Fate of the Asymptotic Slutsky Symmetry Test for Large Systems." Economics Letters 2: 231-233.

Nigel, J., and C. Bogahawatte. 1990. "Demand Systems of Food Using Cross-Section Data: Evidence from Badulla District, Sri Lanka." Tropical Agricultural Research 2: 183-196.

Nirmali, S. A. N., and J. C. Edirisinghe. 2015. "Food Demand Elasticities, Price Changes and Calorie Availability of Households in the Western Province of Sri Lanka." Sri Lankan Journal of Agricultural Economics 12: 15-26.

Pradhan, J., and I. Tudawe (1997). "Food Consumption Pattern in Sri Lanka: An Application of the LA/AIDS Model" Paper presented at the 41st Annual Conference of the Australian Agricultural and Resource Economics Society, Pan Pacific hotel, Gold Coast, Australia.

Rathnayaka, S. D., S. Selvanathan, E. A. Selvanathan, and P. Kler. 2018. "Modelling Sri Lankan Consumption Patterns Using Error Corrected LA-AIDS." Economic Modelling. doi:10.1016/j.econmod.2018.11.006.

Rathnayake, I. M., N. Priyadarshanie, and J. Weerahewa. 2004. "Structural Change in Demand for Cereals in Sri Lanka." Tropical Agricultural Research 16: 292-304.

Sahn, D. E. 1988. "The Effect of Price and Income Changes on Food-Energy Intake in Sri Lanka." Economic Development and Cultural Change 36 (2): 315-340.

Selvanathan, E. A. (1987). "Explanations in Consumer Demand". Ph.D. Thesis, Murdoch University, Western Australia.

Selvanathan, E. A., and K. Clements. 1995. Recent Developments in Applied Demand Analysis: Alcohol, Advertising and Global Consumption. Berlin: Springer-Verlag.

Selvanathan, E. A., and S. Selvanathan. 2003. International Consumption Comparisons: OECD versus LDC. Singapore: World Scientific Publishing Company Private Limited.

Selvanathan, S. 1993. A System-Wide Analysis of International Consumption Patterns. Advanced Studies in Theoretical and Applied Econometrics. Boston: Kluwer Academic Publishers.

Selvanathan, S., and E. A. Selvanathan. 1993. "A Cross-Country Analysis of Consumption Patterns." Applied Economics 25 (9): 1245-1259.
Selvanathan, S., and E. A. Selvanathan. 1994. Regional Consumption Patterns: A System-Wide Approach. Aldershot, UK: Ashgate Publishing Company.

Selvanathan, S., and E. A. Selvanathan. 2004. "Empirical Regularities in South African Consumption Patterns." Applied Economics 36: 2327-2333.

Selvanathan, S., and E. A. Selvanathan. 2006. "Consumption Patterns of Food, Tobacco and Beverages: A Cross-Country Analysis." Applied Economics 38 (13): 1567-1584.

Selvanathan, S., E. A. Selvanathan, S. Albalawi, and M. Hossain. 2016. "Meat and Fish Consumption Patterns in Saudi Arabia." Applied Economics 48 (5): 446-460.

Theil, H. 1965. "The Information Approach to Demand Analysis." Econometrica 33: 67-87.

Theil, H. 1971. Principles of Econometrics. New York: Wiley.

Theil, H. 1975-76. Theory and Measurement of Consumer Demand, Two Volumes. Amsterdam: North Holland Publishing Company.

Theil, H. 1980. The System-Wide Approach to Microeconomics. Chicago: University of Chicago Press.

Theil, H., and F. E. Suhm. 1981. International Consumption Comparisons: A System-Wide Approach. Amsterdam: North-Holland Publishing Company.

Weerahewa, J., C. Rajapakse, and G. Pushpakumara. 2013. "An Analysis of Consumer Demand for Fruits in Sri Lanka. 1981-2010.” Appetite 60: 252-258.

Wong, L., E. A. Selvanathan, and S. Selvanathan. 2015. "Modelling the Meat Consumption Patterns in Australia." Economic Modelling 49: 1-10.

Wong, L., E. A. Selvanathan, and S. Selvanathan. 2017. "Empirical Analysis of Australian Consumption Patterns.” Empirical Economics 52 (2): 799-823.

Working, H. 1943. "Statistical Laws of Family Expenditure." Journal of the American Statistical Association 38: 43-56.

Yang, W., K. W. Clements, and D. Chen. 2003. "The Demand Analysis Package." In International Consumption Comparisons: OECD versus $L D C$, edited by E. A. Selvanathan and S. Selvanathan, 295-320, New Jersey: World Scientific. 


\section{Consumption patterns in Sri Lanka: a decomposition analysis}

\section{Shashika D. Rathnayaka, E. A. Selva Selvanathan \& Saroja Selvanathan}

To cite this article: Shashika D. Rathnayaka, E. A. Selva Selvanathan \& Saroja Selvanathan (2019): Consumption patterns in Sri Lanka: a decomposition analysis, Applied Economics, DOI: 10.1080/00036846.2019.1588950

To link to this article: https://doi.org/10.1080/00036846.2019.1588950

曲 Published online: 21 Mar 2019.

Submit your article to this journal $\pi$

View Crossmark data $₫$ 